Article

\title{
Fires on Ice: Emerging Permafrost Peatlands Fire Regimes in Russia's Subarctic Taiga
}

\author{
Vera Kuklina ${ }^{1,2, *}$, Oleg Sizov ${ }^{3}$, , Elena Rasputina ${ }^{2}$, Irina Bilichenko ${ }^{2}$, Natalia Krasnoshtanova ${ }^{2}$, \\ Viktor Bogdanov ${ }^{2}$ and Andrey N. Petrov $4, *$ (D) \\ 1 Department of Geography, The George Washington University, Washington, DC 20052, USA \\ 2 V.B. Sochava Institute of Geography, Siberian Branch of Russian Academy of Sciences, 664033 Irkutsk, Russia; \\ elenaistoma@gmail.com (E.R.); irinabilnik@mail.ru (I.B.); knesun@mail.ru (N.K.); victvss@gmail.com (V.B.) \\ 3 Oil and Gas Research Institute of the Russian Academy of Sciences, 119333 Moscow, Russia; \\ kabanin@yandex.ru \\ 4 ARCTIC Center, University of Northern Iowa, Cedar Falls, IA 50614, USA \\ * Correspondence: kuklina@gwu.edu (V.K.); andrey.petrov@uni.edu (A.N.P.)
}

\section{check for}

updates

Citation: Kuklina, V.; Sizov, O.;

Rasputina, E.; Bilichenko, I.;

Krasnoshtanova, N.; Bogdanov, V.; Petrov, A.N. Fires on Ice: Emerging Permafrost Peatlands Fire Regimes in Russia's Subarctic Taiga. Land 2022 11, 322. https://doi.org/10.3390/ land11030322

Academic Editors: Baojie He, Ayyoob Sharifi, Chi Feng and Jun Yang

Received: 7 February 2022

Accepted: 18 February 2022

Published: 23 February 2022

Publisher's Note: MDPI stays neutral with regard to jurisdictional claims in published maps and institutional affiliations.

Copyright: (C) 2022 by the authors. Licensee MDPI, Basel, Switzerland. This article is an open access article distributed under the terms and conditions of the Creative Commons Attribution (CC BY) license (https:// creativecommons.org/licenses/by/ $4.0 /)$

\begin{abstract}
Wildfires in permafrost areas, including smoldering fires (e.g., "zombie fires"), have increasingly become a concern in the Arctic and subarctic. Their detection is difficult and requires ground truthing. Local and Indigenous knowledge are becoming useful sources of information that could guide future research and wildfire management. This paper focuses on permafrost peatland fires in the Siberian subarctic taiga linked to local communities and their infrastructure. It presents the results of field studies in Evenki and old-settler communities of Tokma and Khanda in the Irkutsk region of Russia in conjunction with concurrent remote sensing data analysis. The study areas located in the discontinuous permafrost zone allow examination of the dynamics of wildfires in permafrost peatlands and adjacent forested areas. Interviews revealed an unusual prevalence and witnessobserved characteristics of smoldering peatland fires over permafrost, such as longer than expected fire risk periods, impacts on community infrastructure, changes in migration of wild animals, and an increasing number of smoldering wildfires including overwintering "zombie fires" in the last five years. The analysis of concurrent satellite remote sensing data confirmed observations from communities, but demonstrated a limited capacity of satellite imagery to accurately capture changing wildfire activity in permafrost peatlands, which may have significant implications for global climate.
\end{abstract}

Keywords: smoldering fires; zombie fires; boreal forest; permafrost; Evenki; subarctic

\section{Introduction}

With climate change, fires in permafrost underlying areas, including smoldering, peat, and overwintering fires (so-called "zombie fires"), are increasingly becoming a point of concern in the Arctic and subarctic [1-3] amid elevated fire activity in the recent decade [4,5]. Smoldering fires result in more changes to permafrost than rapid flaming fires [6]. The timing and intensity of wildfires in permafrost regions depend on a multitude of factors, such as seasonal permafrost thaw, soil texture, and moisture $[7,8]$. Fires that burn in permafrost peatlands can occur at very low intensities that are difficult to detect by satellite [9]. Overwintering fires are small in size and are often missed by satellites, with most information about them known exclusively from witness accounts [3]. As a result, there is a knowledge gap on permafrost peatland fire basic characteristics, such as locations, conditions, and previous fire return intervals [1].

Peat fires stand out among all wildfires in terms of the amount of combustible material per unit area and in terms of the risks of such fires spreading downward despite increasing moisture content [10]. The release of carbon into the atmosphere as a result of peat fires can reach 15\% of all anthropogenic GHG emissions [11]. For example, estimations of carbon released during the 2010 severe fire in the Moscow region demonstrated that it was 
1.5 times higher per unit area than a typical forest fire [12]. Similarly, high carbon emissions have been observed for major tundra fires [13]. While peat fires occur on all continents and natural zones where bogs are prevalent $[14,15]$, most often they occur and are most threatening for peatlands in the boreal forest zone where low-intensity burning of moss and lichen are the main sources of fuel [16-20]. In contrast with forests where fires can serve as natural regulators of ecosystems, bog ecosystems can be completely destroyed and turned into permafrost-free fens [21,22]. Fire-caused changes in soil chemical composition can also prevent the recovery of bog vegetation for many years [23].

In the permafrost zone, researchers expect an increase in likelihood and intensity of peat fires as a result of climate change and growing anthropogenic impacts $[14,24-27]$. The catastrophic wildfires of recent years in permafrost areas have been located in areas of intensive extractive industrial development, such as the Republic of Sakha (Yakutia) [28] and the Irkutsk region $[29,30]$. These regions are considered to have limited transportation accessibility; however, infrastructure development including transportation infrastructure there are quite significant [31]. In areas with permafrost even the winter roads have a significant impact on carbon exchange [32]. Responding to wildfires in tundra and taiga areas with permafrost and limited transportation accessibility is challenging for traditional fire management; different mechanisms and strategies may be required to prevent and fight wildfires compared to those typically implemented in the boreal zone. The wildfires of 2021 in Yakutia demonstrated that it takes a tremendous amount of resources to put out fires in such conditions [33]. Therefore, effective means for monitoring permafrost peatland fires and understanding their causes and other characteristics are in high demand yet remain largely underexplored.

To improve the understanding and monitoring of wildfires, researchers increasingly rely on collaboration with local and Indigenous communities. Local and Indigenous input can be useful for framing questions, providing guidance to locate ground observations, and for the interpretation of data [34]. This collaboration could be especially useful for detecting and examining low-intensity fires that take place in permafrost-underlying regions. In addition to understanding what different kinds of wildfires mean for local and Indigenous communities and the manners in which they may affect subsistence activities, engaging local and Indigenous knowledge is an important task in terms of assessing local risks and responses to fire events in remote areas.

This paper presents a novel approach to collaborating efforts of researchers and local and Indigenous communities in exploring emerging fire regimes in the permafrost areas of Russia's subarctic taiga that are being affected by new infrastructure development. We aim to provide a comprehensive understanding of wildfire activities across different types of taiga landscapes at the local scale. For that purpose, we are bringing together diverse sources of information which include the authors' own landscape observations, local and Indigenous communities' input, and remote sensing data. First, we examine different types of landscapes distinguished by local and Indigenous communities, by landscape observations, and land cover classification. Second, we learn from local communities about wildfire characteristics they observe across the different landscapes. Then, we utilize satellite active fire data products in order to elucidate the general dynamics of wildfires across years, seasons, and landscapes. Finally, we complement these data with local and landscape observations that satellite sensors have been unable to capture. Based on these findings, we discuss the evidence of increased permafrost peatland fire activity in subarctic taiga and the growing role of Indigenous and local communities in providing unique information about emerging permafrost peatland fire regimes, including smoldering and overwintering fires.

\section{Study Area}

This paper focuses on the Siberian taiga near the villages of Tokma and Vershina Khandy in the Irkutsk region of Russia (Figure 1). These study areas are characterized by harsh (and changing) climatic conditions, discontinuous permafrost, the prevalence of conif- 
erous vegetation, and susceptibility to wildfires [35-37]. The region has been historically settled by Evenki, Indigenous Tungus-speaking people who have traditionally subsisted on hunting, fishing, and gathering Siberian pine nuts, berries, and herbs. Moreover, some Evenki view reindeer as protectors of the landscape and its beings. Reindeer pastures traditionally were considered to be free from wildfires [38]. According to interviews gathered by Anna Sirina [39], the Evenki regard wildfires as a punishment inflicted on humans by high spirits. She also refers to a wide variety of Evenki terms for places affected by wildfires which demonstrate their rich experience of encounters with wildfires.

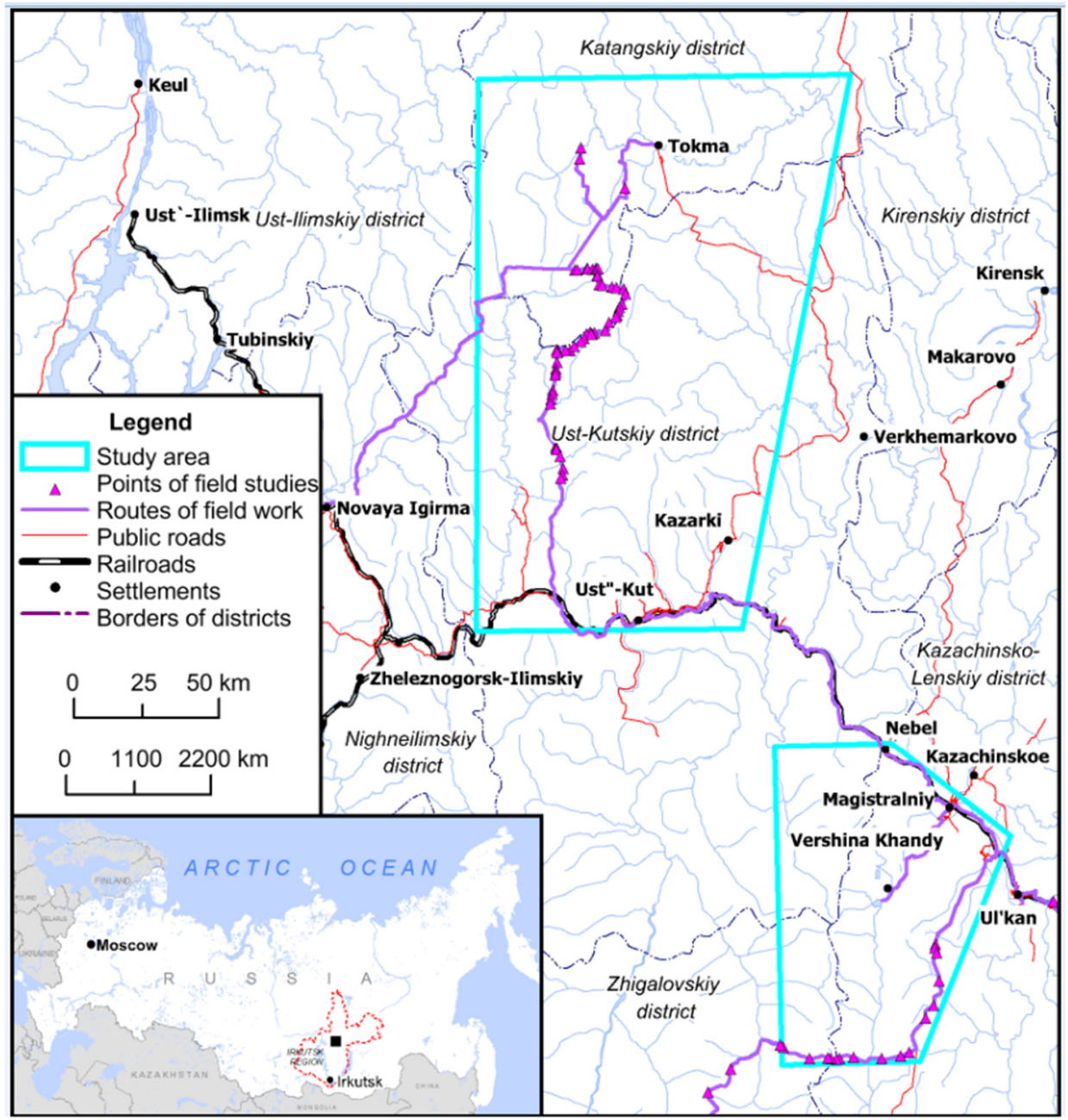

Figure 1. The study areas.

The Tokma study area (2107 thousand hectares) includes the Evenki village of Tokma and the Yaraktinskoie and Ichodinskoie oil fields. Infrastructure development is conditioned by the expansion of oil and forest industries in addition to geological explorations. It includes the area allocated for traditional land use of an Evenki obshchina (community hunting enterprise) "Tokma" with 20 members from the village (total 1115 thousand hectares). The Khanda study area (696.5 thousand hectares) is centered around the Evenki village of Vershina Khandy and includes the town of Magistralny and the area of the Kovyktinskoie gas field. The village has no official road connection (distance to Magistralny about $36 \mathrm{~km}$ ). The Kovyktinskoie gas condensate deposit was discovered by geologists in 1987 and is known as the biggest gas deposit in the Russian East [40]. By 2022 it is expected to become the main source for the Power of Siberia gas pipeline. Forestry and geological exploration companies are also active in the area. The Khanda site includes the area of traditional land use of an Evenki obshchina "Khandinskaia" with 71 members (299.1 thousand hectares). 
Despite being at the epicenter of rapid extractive industrial development, the local communities of Vershina Khandy and Tokma are lacking official permanent roads, mobile phone connectivity, and power lines. As such, they are included in the government list of territories with seasonal transportation accessibility; this affects wildfire management regulations for the delivery of ground transportation to suppress fires. Southern parts of the study areas are located in the zone where both airborne and satellite monitoring of wildfire are implemented, but in its northern parts authorities conduct only satellite monitoring unless wildfires threaten settlements and/or important infrastructure [41]. Wildfire management is administered by the Department of Forest Protection of the Irkutsk regional Ministry of Forestry. It coordinates the work of local forestries that are responsible for fire prevention and control on the ground [42]. Irkutsk Aerial Forest Protection Service (Avialesookhrana) is responsible for monitoring fire situations using airborne technologies; receiving and recording messages about forest fires; sending alerts to both populations and fire fighting services; giving operational assessments of fire risks as well as ongoing forest fires; and extinguishing wildfires using aircraft [42].

With expanding extractive industrial development, different kinds of infrastructure have been built in the study areas, including oil service and forest access roads. There are also multiple, non-related users in the forest, from oil and forestry companies to geological and construction crews, as well as local hunters and fishers. Wildfires exacerbate disturbances caused by infrastructure development and forestry. In particular, the wildfires of July 2019 were characterized as anomalous for Siberia with record burned areas and related harmful atmospheric emissions [29]. According to the Minister of Forestry of the Irkutsk Region, 27\% (153) of fires in the region in 2021 were caused by humans, with most occurring near settlements. However, another important cause of fires is forestry activity when companies improperly burn waste from logging [43]. According to current legislation, each forest owner and tenant maintains their own means for preventing and suppressing wildfires. Forest users are obliged to maintain wildfire safety, which includes fire prevention, monitoring, and development of wildfire response plans $[44,45]$. However, quite often such users lack resources and capacities to extinguish fires.

\section{Materials and Methods}

The study consisted of several stages reflecting an iterative process of collaborative knowledge production where local and Indigenous communities informed and guided the direction of the research. The research questions emerged from early conversations with community members, and were formulated during desktop research first, tested during field work, revised during analysis, and refined during the second field season upon receiving community feedback. The local and Indigenous knowledge component that played a leading role in this study was supplemented by landscape and remote sensing data collection and analysis aimed at placing local observations in context with other observing systems.

\subsection{Local and Indigenous Knowledge Component}

This article is based on data collected in 2019 and 2021 from the village of Vershina Khandy, and in 2020 and 2021 from the village of Tokma. We conducted 49 in-depth interviews with local community members and stakeholders both in the study areas and in Irkutsk (the regional capital), along with participatory mapping, participant observations, and travel by informal roads in summer and winter. The interviewees were recruited using the snowball method: we asked our main partners to help with recruiting other participants who in turn helped with finding other respondents. Originally, the main focus of interviews was about the locations and development of informal roads and their social and environmental impacts. However, concerns over wildfires around settlements and informal roads emerged as a key theme from study participants. During the first field trips (in 2019 and 2020) study participants interacted with printed maps of the study areas $(1: 200,000)$ developed using Landsat imagery. The interviewees were asked to locate 
informal roads that they encountered during travel, whether they knew the origins of such roads, and what environmental and social implications were attached to those roads. During the second visit, we brought maps with digitized roads based on their input, along with very high-resolution images (WorldView and GeoEye from 2019 and 2020), and asked participants to locate major disturbances they encountered and how those disturbances may have been related to infrastructure development. We created a vector layer with locations of disturbances in the forms of points and polygons using an offline version of Google Earth.

All interviews were transcribed. The data were coded and analysed in order to identify persistent topics using NVivo software. Based on the analysis, we extracted the topics of fire and permafrost, examined the contexts in which these topics were mentioned, and investigated when and how the topics intersected. Wildfires were mentioned in 33 interviews. In the same pool there were 12 interviewees who mentioned permafrost. Among the interviewees, fires were the most discussed topic among male hunters and experts, including representatives of local authorities, a forestry company, an oil company, and a former representative of forestry management. The male bias (26/7) is a result of the fact that most observations were provided by hunters and forestry workers, predominantly male occupations (Figure 2).

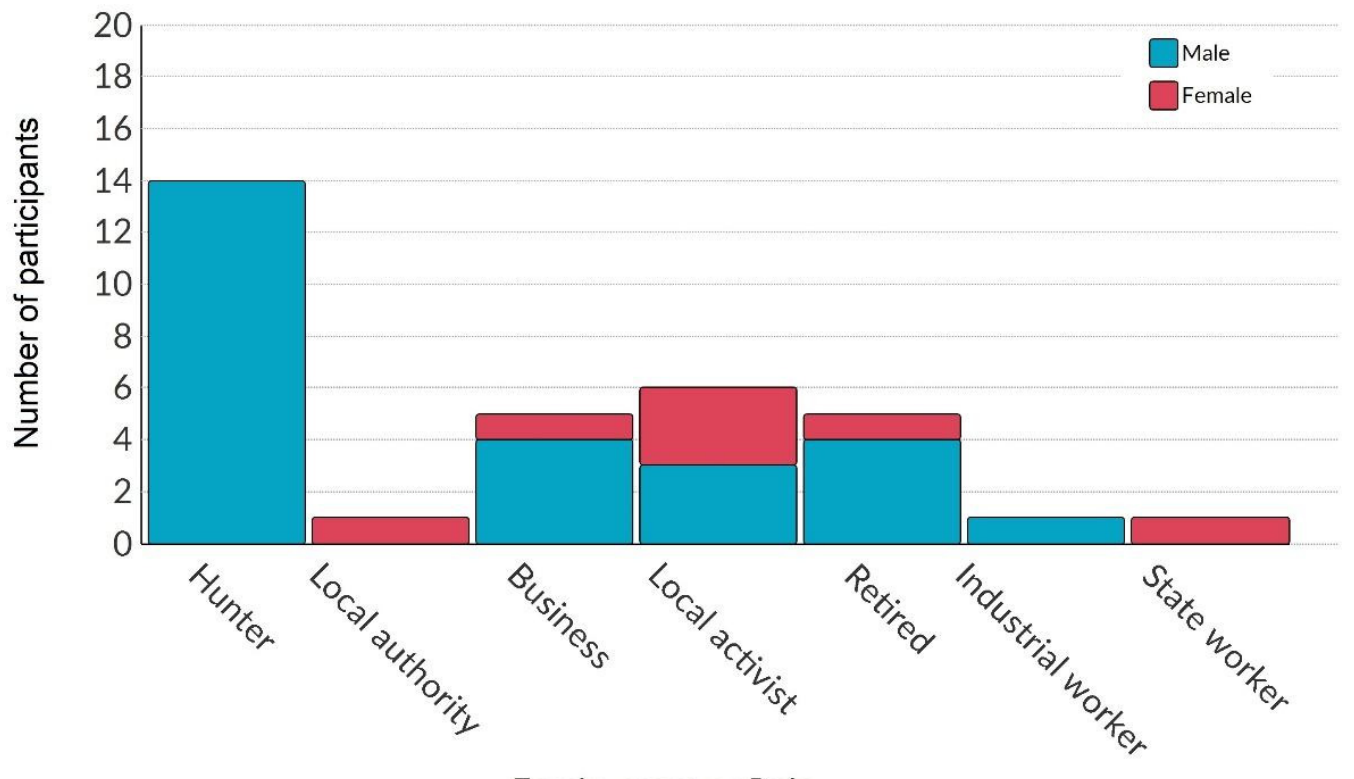

Employment or Role

Figure 2. Demographics of interviewees discussing the topic of wildfires.

The interviews and GIS data were used for determining the questions for remote sensing analysis and for planning the landscape studies.

\subsection{Landscape Component}

The landscape component incorporated fieldwork from the study sites during the summer of 2021. Before commencing field studies, we carried out a preliminary analysis of available satellite imagery. At this stage, we used visual inspection of Sentinel-2 and imagery obtained using Google EarthTM, Yandex, and ESRI with the nearest dates available to those of the field work (summers of 2019-2021). We manually selected observation points in different landscapes along the planned travel route. In the field, the following details were carefully examined and recorded: the relief, vegetation, and soil characteristics; the climatic and hydrological features; and anthropogenic disturbances. Particular attention was given to the description of vegetation as the main component of the landscape, which is greatly affected by fires. The vegetation characteristics included descriptions of the 
forest stand, undergrowth, and grass-dwarf shrub layer. Approximately 200 locations were described between the two study areas.

To understand relationships between wildfire characteristics and weather conditions we obtained data on precipitation and temperature from the weather stations located in the village of Tokma in the Tokma study area, and in the village of Kazachinskoie in the Khanda study area. We examined continuous data series from Kazachinskoie station for temperatures available since 1943, and for precipitation since 1938. Continuous temperature and precipitation data series for Tokma station are available since 1950. For these weather stations, the norms of temperature and precipitation for a 30-year (1961-1990) period were acquired from the Irkutsk Hydrometeorological Service. The 2002-2020 anomalies in selected climatic characteristics were examined for the warm May-October period in order to capture the fire season.

\subsection{Remote Sensing Component}

For land cover mapping and analysis, we acquired and analyzed Landsat 8 images using the Google Earth Engine (GEE) platform. Two time periods were chosen for analysis: the summer of 2013-2014, the period closest to the field studies year with a minimum area of fresh fire burns; and the summer of 2018-2019, which featured devastating wildfire seasons in both study areas. We obtained surface reflectance bands for the periods from June to September of 2013, 2014 (94 images for Tokma and 61 for Khanda key areas), 2018, and 2019 (83 images for Tokma and 63 for Khanda key areas). We masked out clouds with quality flags available from GEE [46]. The two-year composites were used as a result of the small numbers of cloud-free Landsat images for this region. Based on these composites, we calculated median values of cloud-free pixels of these images for bands B3-B7. We classified image composites into seven classes (Table 1) using the random forest classifier (300 trees, 5 variables per split) [47]. We used about 200 test polygons for each study area (including more than 1000 test pixels, $80 \%$ of the points to train the algorithm and $20 \%$ for accuracy assessment). About half of the test polygons were based on data collected during the field trip in July of 2021, and about half were obtained from a mosaic of Sentinel-2 images (for the dates 7 July 2019 and 13 August 2018 from the Khanda area, and 27 July 2021, 5 July 2020, and 5 July 2019 from the Tokma area), in addition to the most recent very high-resolution (VHR) imagery available from Google EarthTM, Yandex, and ESRI. In order to understand the extent of wildfire propagation across different landscapes we calculated the extent of 2014-2019 burned areas for each type of land cover. In order to determine relative fire rates for various land cover types in 2013-2014 to 2018-2019, the burned areas within each type of landscape were divided by their respective total areas in 2013-2014, resulting in burned areas as a percentage of each land cover class.

Table 1. Burned areas by types of land cover.

\begin{tabular}{|c|c|c|c|c|c|c|}
\hline \multirow[b]{2}{*}{ Class } & \multicolumn{3}{|c|}{ Khanda } & \multicolumn{3}{|c|}{ Tokma } \\
\hline & $\begin{array}{l}\text { 2013-2014, } \\
\text { Square km }\end{array}$ & $\begin{array}{l}\text { Change in Burned } \\
\text { Areas from } 2013 \text { to } \\
2019, \text { Square km }\end{array}$ & $\begin{array}{c}\text { Change in Burned } \\
\text { Areas from } 2013 \text { to } \\
2019, \%\end{array}$ & $\begin{array}{l}\text { 2013-2014, } \\
\text { Square km }\end{array}$ & $\begin{array}{l}\text { Change in Burned } \\
\text { Areas from } 2013 \text { to } \\
2019, \text { Square } \mathrm{km}\end{array}$ & $\begin{array}{c}\text { Change in Burned } \\
\text { Areas from } 2013 \text { to } \\
2019, \%\end{array}$ \\
\hline Forest & 4055.2 & 257.8 & 6.36 & $16,311.7$ & 2936.2 & 18.00 \\
\hline Woodland & 1169.6 & 113.1 & 9.67 & 466.7 & 145.7 & 31.22 \\
\hline Peatlands & 686.3 & 44.5 & 6.48 & 3796.8 & 1560 & 41.09 \\
\hline $\begin{array}{l}\text { Anthropogenic } \\
\text { landscape }\end{array}$ & 56 & 2.6 & 4.64 & 233.3 & 53.1 & 22.76 \\
\hline Burned areas & 140.1 & 35.9 & 25.62 & 381.8 & 183.3 & 48.01 \\
\hline Other * & 868.6 & 51.3 & 12.9 & 424.3 & 49.6 & 30.9 \\
\hline
\end{tabular}

* Meadows, agricultural lands, shrubs, and barren land. 
For examining wildfire characteristics and their timing we used several sources and methods. First, we examined active fires in 2014-2021 using data on thermal anomalies from MODIS and VIIRS imagery [48-50]. The archived data from MODIS Collection 6.1 (2000 to present) and VIIRS S-NPP 375 m (2012 to present) were obtained from NASA's Fire Information for Resource Management System (FIRMS) [51,52]. The data were documented in point-based vector format (i.e., shapefile) with information on fire occurrence (day/night), fire location, Fire Radiative Power (FRP) values, and numerous other attributes. These data were aggregated by dates, and by peatland versus non-peatland types of land cover. FRP information was used to determine fire intensities [53]. We manually removed gas flares from oil production sites as they have stable temperatures and locations that are also visible on Sentinel-2 images. Data on annual cumulative Fire Radiative Power (FRP) from VIIRS and combined MODIS Aqua and MODIS Terra were used to provide general understanding of annual changes in fire activity relative to temperature and precipitation anomalies at weather stations in the study region. Finally, we examined fire data from MODIS and VIIRS in locations identified from local residents' interviews as spots with smoldering peatland fires. We also used contemporaneous Sentinel-2 and WorldView satellite images for a detailed visual inspection of these areas.

\section{Results}

\subsection{Local Taiga Landscapes and Wildfires}

During the last decade, wildfires in the study region were very intensive (Figure 3). For example, in multiple years between 2014 and 2019 the annual cumulative FRP exceeded the combined intensity observed for all previous years. A comparison of temperature and precipitation anomalies during the warm period of the year (May-October) at Tokma and Kazachinskoie weather stations with satellite FRP data revealed a number of important patterns. For the Tokma area, both MODIS and VIIRS sensors detected significant FRP increases during dry years independent of the air temperature changes. In contrast, in the Khanda area the intensity of fires increased concomitantly with air temperature, although a coincidence with depressed precipitation was also observed.

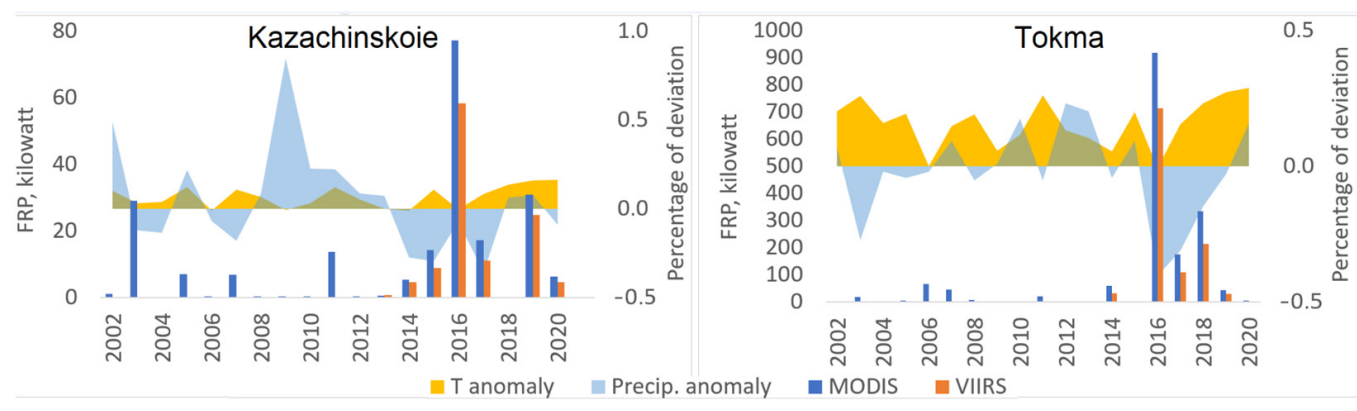

Figure 3. Dynamics of annual cumulative Fire Radiative Power (FRP) changes, and temperature and precipitation anomalies at weather stations in the study areas.

Interviews with local and Indigenous community members supplemented by field studies of landscapes allowed us to identify key landscape types affected by wildfires (Figure 4). Note that specific landscape features could be related to permafrost occurrences. Landscapes' significance for traditional subsistence activities varied in addition to their propensities to burn. Coniferous forest with larch, pine, and cedar is dominant in the study region. Among the different kinds of trees, the Evenki value forests with cedar as a habitat for sable and as a source of pine nuts [54]. Sparse larch and spruce-larch with dwarf birch forests occupy watershed surfaces and the upper parts of slopes. Larch and pine-larch, larch-pine subshrub-green moss, and herb-green moss forests are located on lower slopes. According to Suvorov and Makarov [36], these types of forests represent recovery stages after the disturbance of primary dark coniferous forests by logging and fires. Restorative series of birch, aspen-birch herb-green moss forests are also common in the area but are 
less valuable for local communities. Valleys and slopes facing rivers are covered with larch and pine-larch lingonberry-forb forests, in addition to larch forests with an admixture of cedar and spruce shrub-moss in combination with sparse larch-dwarf birch forests. In the areas with recent fire scars vegetation recovery has just commenced with the growth of fireweeds (Chamérion angustifolium).

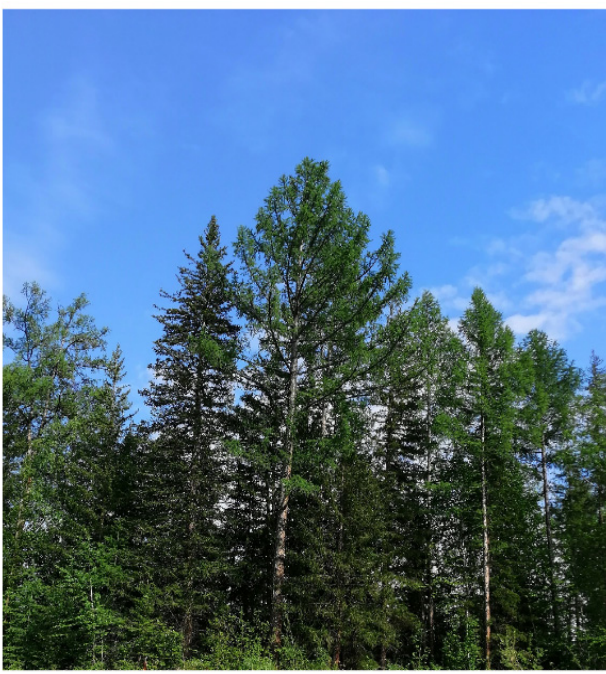

(a)

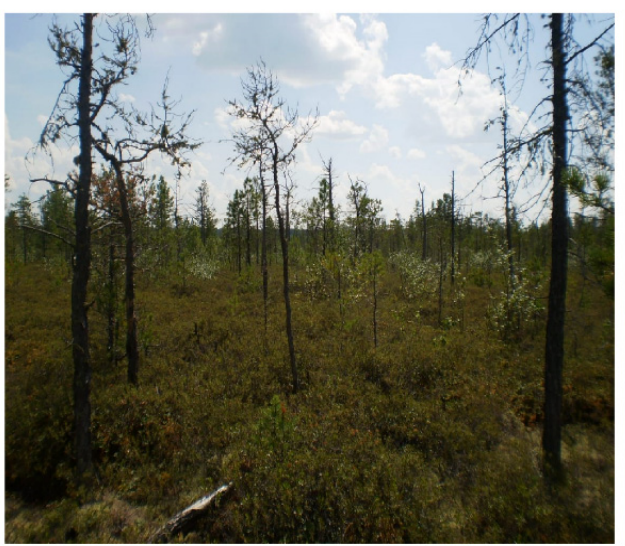

(c)

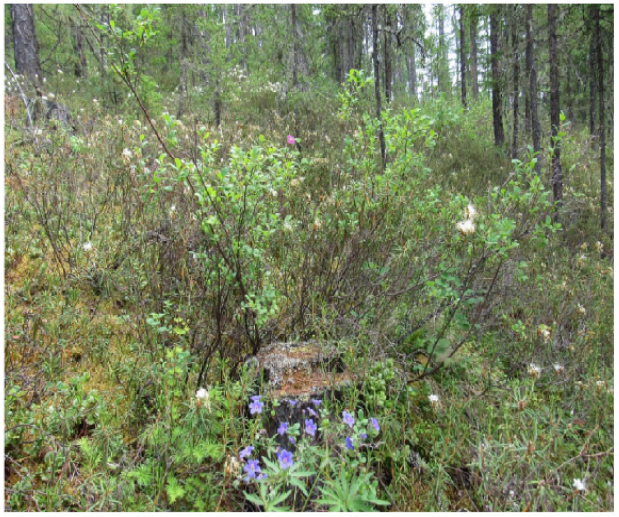

(e)

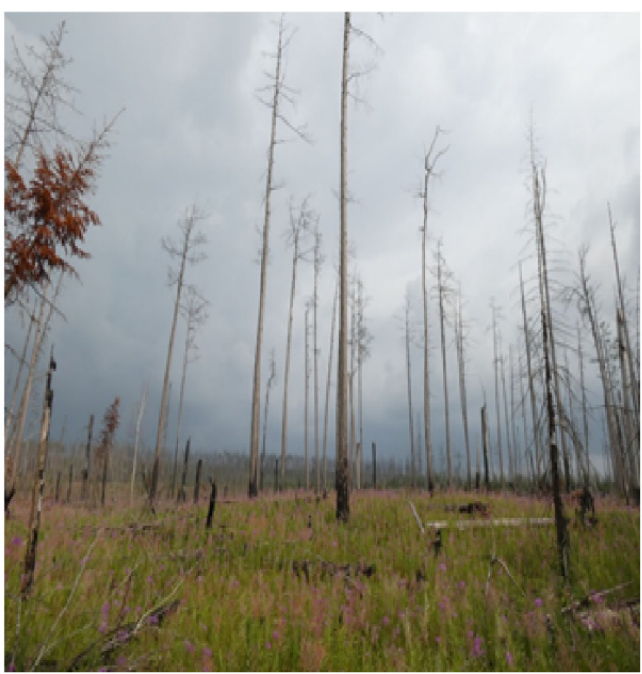

(b)

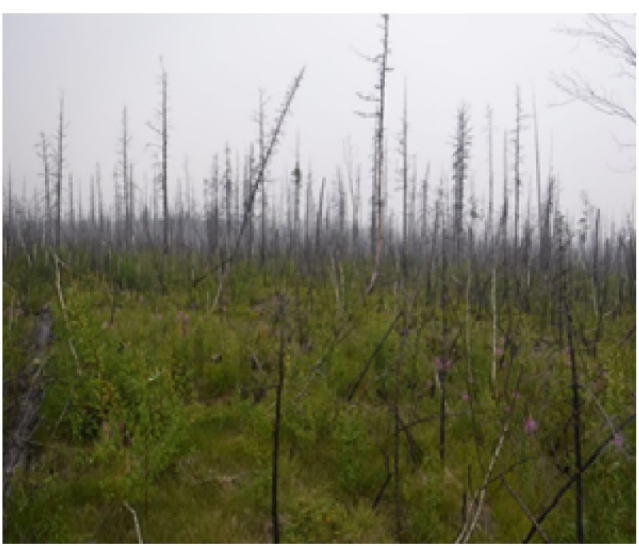

(d)

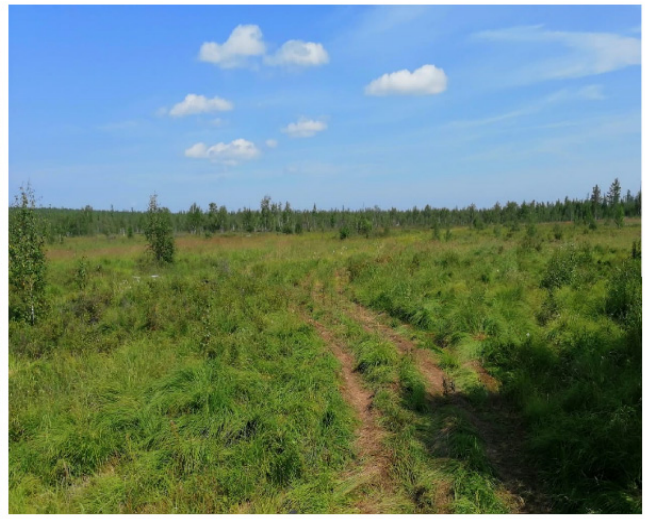

(f)

Figure 4. Examples of taiga landscapes: (a) coniferous forest; (b) forest burned in 2019; (c) tundra or mar' (swampy forest); (d) swampy forest burnt in 2018; (e) navolok; (f) kaltus. 
Peatlands occupy river valleys and intersperse with forbs meadows. Bogs in peatlands are mainly represented by sparse larch forests with marsh wild rosemary, sedge, and cranberries with a thick moss cover. They have served as places for local gatherings of cloudberry and cranberry. Significant for local communities are yernik-different types of dwarf birch with lichen and moss. After most of the old growth forest was burnt or logged, yernik became the main area for lichen and moss growth to attract reindeer as their pasturelands. However, one of the residents of the local community noted that wildfires occur from time to time and burn for longer durations when they reach peat and other swampy lands locally known as tundra, navolok, and kaltus (Figure 3). Tundra differs from the scholarly definition of tundra; in the local sense it refers to rather swampy, sparse forests with underlying permafrost; in Russian academic literature it is often identified as mar' (a term borrowed from Evenki language) [55]. Kaltus is a seasonally drying swampland with shrubs and dwarf birch overtaking the place of sedge and sphagnum; it is important for local residents as a moose pasture. Navolok is a wet ecotone with an abundant moss cover and sparse trees on slopes as a transitional zone between wetlands, rivers, lakes, and forest: "the lowland, with rare trees, as we usually call it, a navolok, with small spruce and cedar trees" (male, 56, Tokma, 5 August 2021).

While currently both Tokma and Khanda Evenki do not practice reindeer herding, wild reindeer still serve as their main source of meat. Changes in vegetation affect reindeer, which rely on moss and lichen in wintertime. After peatlands burn, moss and lichen used by moose and reindeer are succeeded by grass. This causes changes in migration routes of reindeer, making it more difficult for hunters to procure food during winter. The fires on kaltus also create a danger of falling into holes formed by burned-out peat. Landscape observations of the bogs burned four years ago confirmed the decrease in the proportion of bog vegetation and its replacement by grass.

For land cover classification, we discerned classes that were distinguishable in the Landsat 8 imagery and relevant for local communities' narratives of wildfires, including burned areas themselves. In particular, we combined different types of forest into one class. Sparse larch and spruce-larch forests with yernik in undergrowth formed a separate class of woodland. The peatlands class is formed by swampy yernik with sparse larch and spruce stands, tundra - sedge bogs with cranberries and wild rosemary, and navoloks. Settlements and areas with almost no vegetation as a result of human activity, such as recent logging and gravel mining sites, seismic line clearings, infrastructure for the oil and gas industry, and agricultural lands, were classified as anthropogenic landscapes. We also isolated burned areas in a separate class.

For accuracy assessment, approximately 40 test polygons were used for each study area, 20 of which were identified using field description points, meaning that about $50 \%$ were based on ground truthing. The remaining polygons were based on brightness and texture characteristics from satellite images, similar to those described in the field. Overall accuracy of the land cover classification was 0.96-0.98 (supplemental material, Table S1). The resulting land cover maps demonstrate that from 2014 to 2019 burned areas increased from $2 \%$ to $6 \%$ in the Khanda area and from $2 \%$ to $23 \%$ in the Tokma area in the aftermath of the extensive fire seasons of 2016, 2018, and 2019 (Figure 5). Although a significant area was damaged by wildfires, boreal forest still covered most of the study regions (about 50\% in the Khanda area and $47 \%$ in the Tokma area), while peatlands occupied about $10-15 \%$ of the territory (Figure 5). In addition, while anthropogenic landscapes are very scarce, they expanded about three times in Khanda (from 0.8 to $2.3 \%$ ) and ten times in the Tokma area (from 1.1 to $11.2 \%$ ) as a result of forestry and infrastructure development.

Analysis of burned areas across different types of land cover demonstrated that previously burned areas were the most prone to burning ( $26 \%$ of burned areas had at least one new fire event in Khanda and 48\% in Tokma) (Table 1). Most of the land affected by wildfires was covered by forest. However, the proportion of burned areas was higher for peatlands. For instance, in Tokma $41 \%$ of peatlands and $31 \%$ of woodlands experienced fires. Woodlands around Tokma have shrunk almost by one third as a result of wildfires. In 
the Khanda region, the woodlands land cover type was the most affected by fires, followed by peatlands and forest.

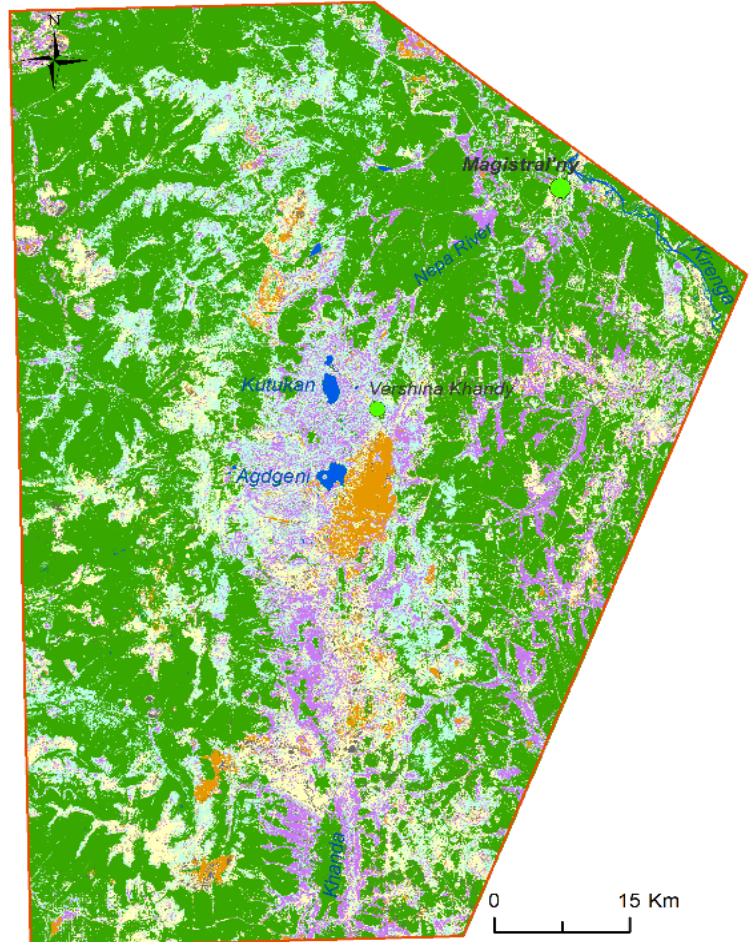

(a)

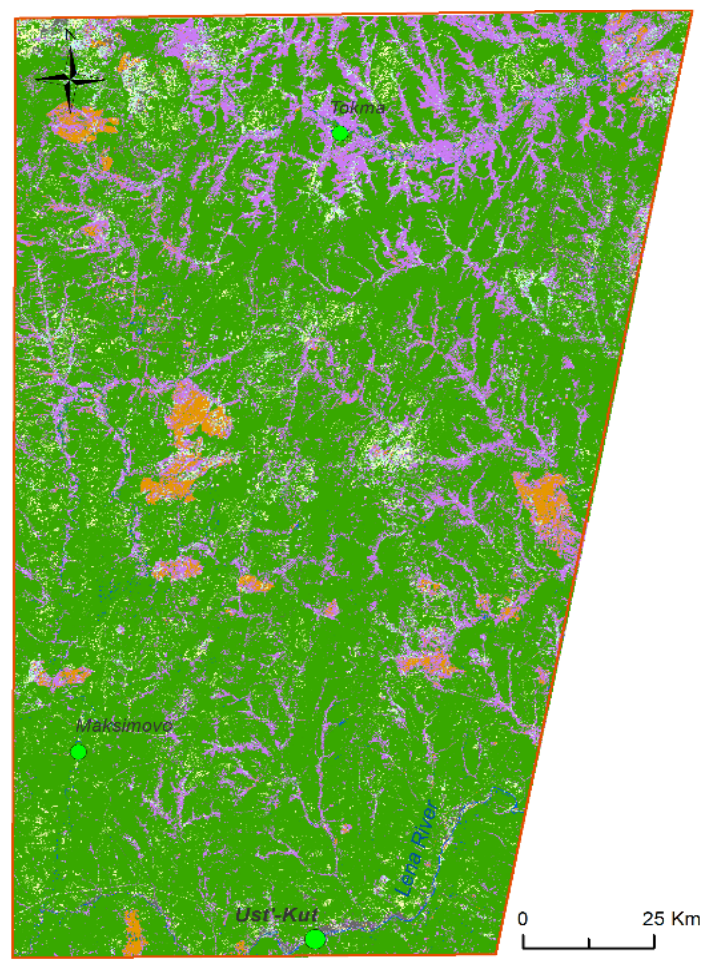

(c)

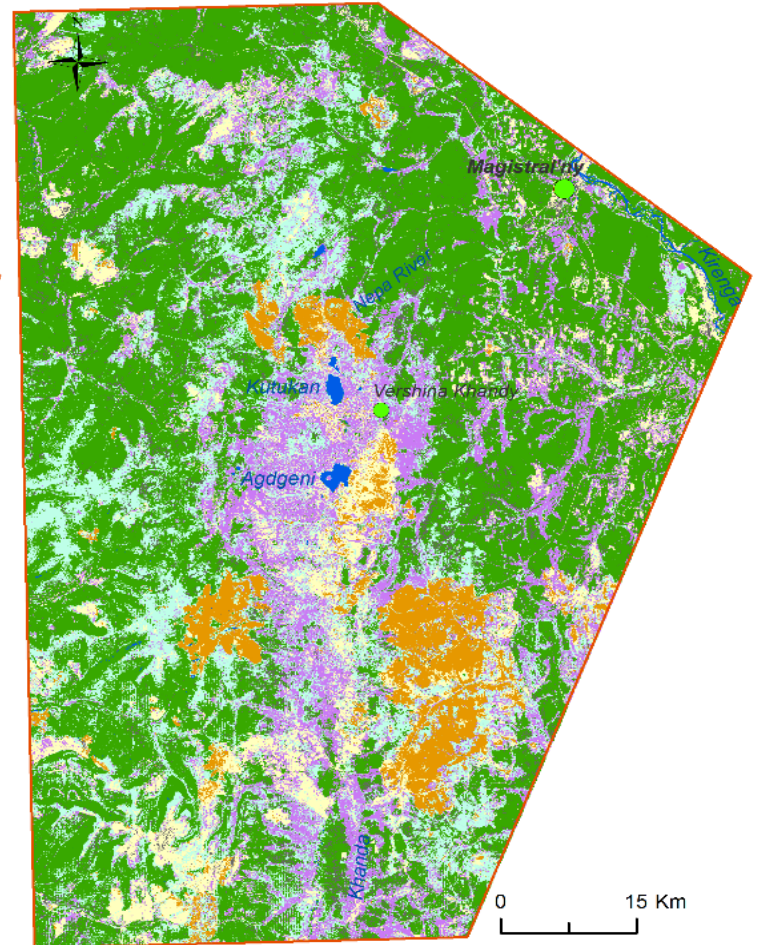

(b)

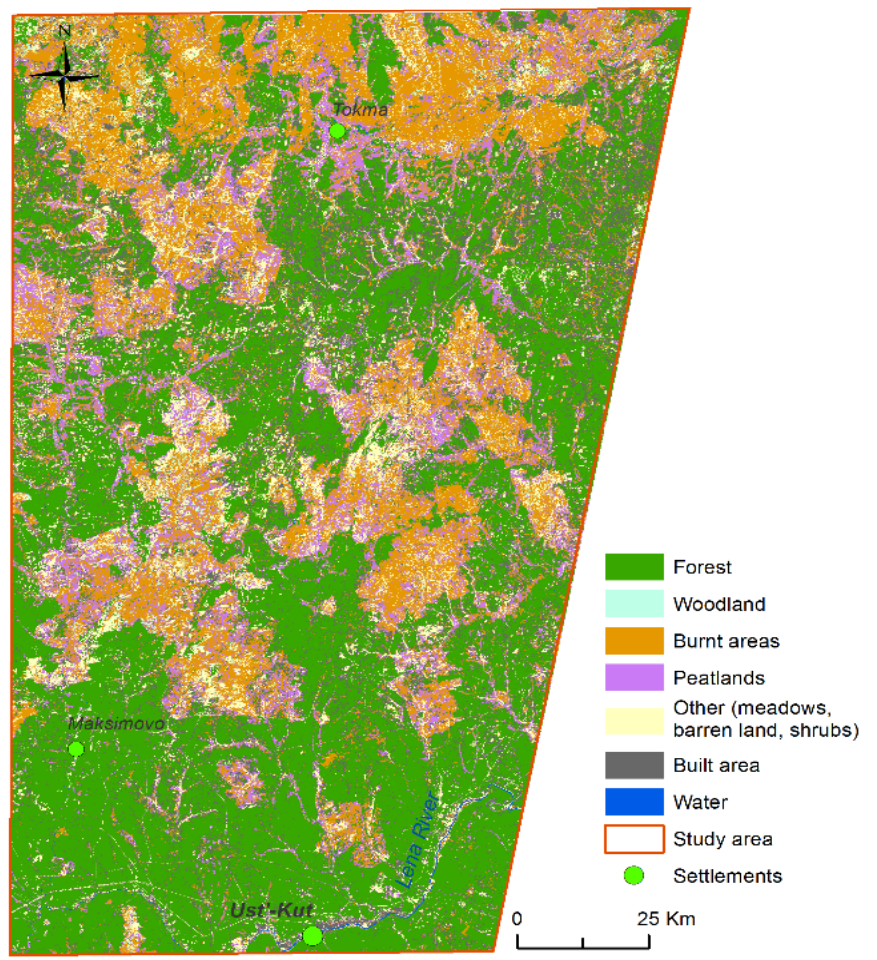

(d)

Figure 5. Types of land cover in the study areas: (a)—Khanda area, 2014; (b)—Khanda area, 2019; (c)-Tokma area, 2014; (d)—Tokma area, 2019. 


\subsection{Local Accounts of Wildfire Occurrences and Management over Permafrost Areas}

In the study areas, local residents encounter wildfire management efforts by forestry service when fires approach settlements, and by private forest companies when fires damage their rented areas. In situations when neither forestry service nor private companies are involved in firefighting, there are some instances of local dwellers' individual efforts to monitor and extinguish fires.

For wildfire monitoring purposes, residents connect with their urban friends and families who use NASA FIRMS-based data for locations and expansions of fires. During fire season, updates on wildfire locations were the first theme raised in conversations with the locals. When hunters learn that a fire is approaching their hunting grounds, they promptly proceed to their sites and pour water over the walls of their hunting huts (each hunter has several huts where he stays during the hunting or fishing season). Usually, these huts are built by the hunters themselves or with support from relatives and friends using wood from the surrounding forest and occasionally materials purchased in stores. For example, one hunting hut was burned two years after it was built. Difficulties with rebuilding huts were mentioned by aging hunters as a reason to quit hunting. In addition, the locals have to deal with debris formed by fallen trees on their subsistence roads, which not only hinder vehicle movements, but also bury hunting traps installed along pathways. Debris removal is also one of the urgent tasks for hunters in case of wildfires. Therefore, local hunters consider damage caused by fires in terms of their time and effort spent on preparation, mitigation, and reconstruction, rather than in terms of direct financial losses, something usually counted by public officials.

Wildfires in permafrost peatlands were often mentioned in relation to changes in vegetation and permafrost degradation. In addition, local residents accumulated significant knowledge on locations, causes, and characteristics of peatland fires. They noted that the active fire period varies and extends the longest in swampy areas such as kaltus, and that fires may last up to three years. Tundras are also characterized by longer periods of burning than regular forest, although not for as long as ordinary peatlands. Permafrost layer is perceived as a protector against deeper burning, as was mentioned by the following interviewee:

K. hunted there in Iryshki, there are swamps there. Back in January, well, or November, I won't say for sure, the tundras were burning, they burned for a long time, well, there is such a layer of moss, the moss was moving away, they burned and burned, and they could also snuggle up to the ridge and jump out slowly, and the trees fall. They all went out by the spring, did not stay for another summer. We have swamps, there is still permafrost, it wouldn't give [way to the next year burning] (male, 45, 5 August 2021, Tokma).

Areas with permafrost are often overlooked by fire management agencies and satellite monitoring. According to a former wildfire protection official, forestry agencies consider satellite monitoring in the areas with permafrost as a most sensible approach, as was mentioned by the following interviewee:

They see $300 \mathrm{~km}$ from fire to the settlement, and $50 \mathrm{~km}$ - to a river through which the fire will not pass. People can be thrown over $1000 \mathrm{~km}$, and it still makes no sense. And if there is, first of all, permafrost, the number of swamps and streams. That is, there is a weak ground fire, vapors conceal this and do not cause significant harm, it reaches the limit to some larger stream of the river, it will stop. Basically, the permafrost begins to burn superficially, water begins to thaw, after all, it enters the Katangsky region: the hotter the summer, the more water. I have not seen peat fires there during my 4 years of work, when I was dealing with fires. Surface fires are going on, occasionally turning into crown fires somewhere to some distance, and turning again into surface one, that's it. In the Katanga region there is not much dry peat, there is permafrost immediately (male, 60, 26 Jun 2021, Irkutsk).

This interview provides evidence of the lack of knowledge, in addition to the neglect and deprioritization, of low-intensity fires over permafrost peatlands. In contrast, a forest company representative who was directly dealing with wildfires noted the occurrences 
of peatland wildfires during dry years. He emphasized the contrast between peatland wildfires and regular forest wildfires, stating that fires in swamps and yernik are more difficult to manage since they are less accessible to firefighters. Heavy machinery risks either becoming stuck in a swamp or falling through burned peat. He observed that in such areas, fires smolder for a long time, including in winter. While fire suppression measures are lacking in these areas, they are highly important for local communities given the considerable impacts of peatland wildfires on residents' livelihoods.

\subsection{Peatland Fires and Dynamics of Fire Activity in Permafrost Areas}

The analysis of average annual fire intensities for years 2001-2020 using MODIS images in peatlands versus other landscapes demonstrated comparable values (Figure 6). Variability was higher in non-peatland areas in Tokma, and in peatlands in Khanda where peatlands occupy larger areas.

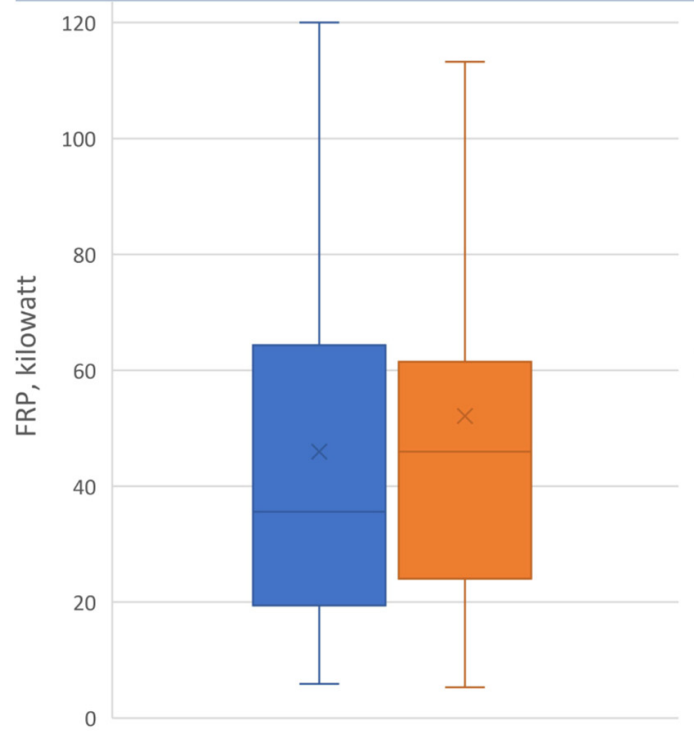

(a)

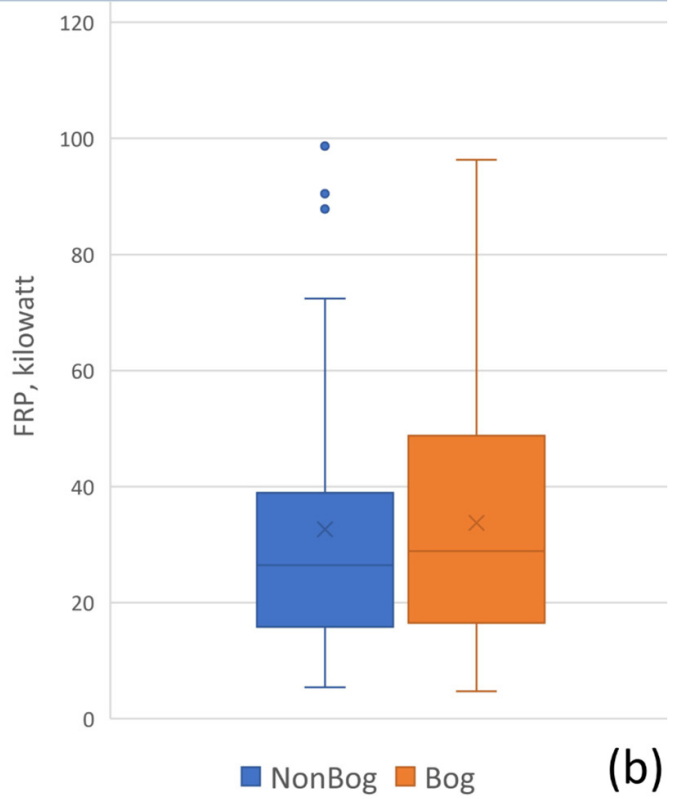

(b)

Figure 6. Boxplot with average annual FRP values in peatlands and other areas: (a) - Tokma area; (b) - Khanda area.

The analysis of seasonal wildfire dynamics using satellite data showed that the intensities of combustion in peatlands and in forest are comparable throughout the year according to two different sensors (Figure 7). MODIS Aqua night-time values were generally higher for peatlands than for other areas in both study sites. In addition, according to MODIS daytime data for the Tokma area, peatland fires demonstrated higher FRP values than those in other landscapes. There was a higher intensity of fires in the beginning of the summer in forest landscapes than in bogs, with higher values of FRP in April than in May. In some cases, we see that forest fires are rarely detected in fall, while in swamps they still exist (e.g., Aqua night data in the Khanda area and VIIRS night data in the Tokma area). In October, thermal anomalies in peatlands were not recorded. The differences in FRP values observed by different satellites are related to both their instrument characteristics and landscape features. In particular, higher values of daytime data are related to the duration of daylight hours. VIIRS has lower absolute values (this can be caused both by the sensitivity of the sensor and by calibration features [56,57]), while MODIS Aqua and Terra satellites have comparable data both in dynamics and in average. 

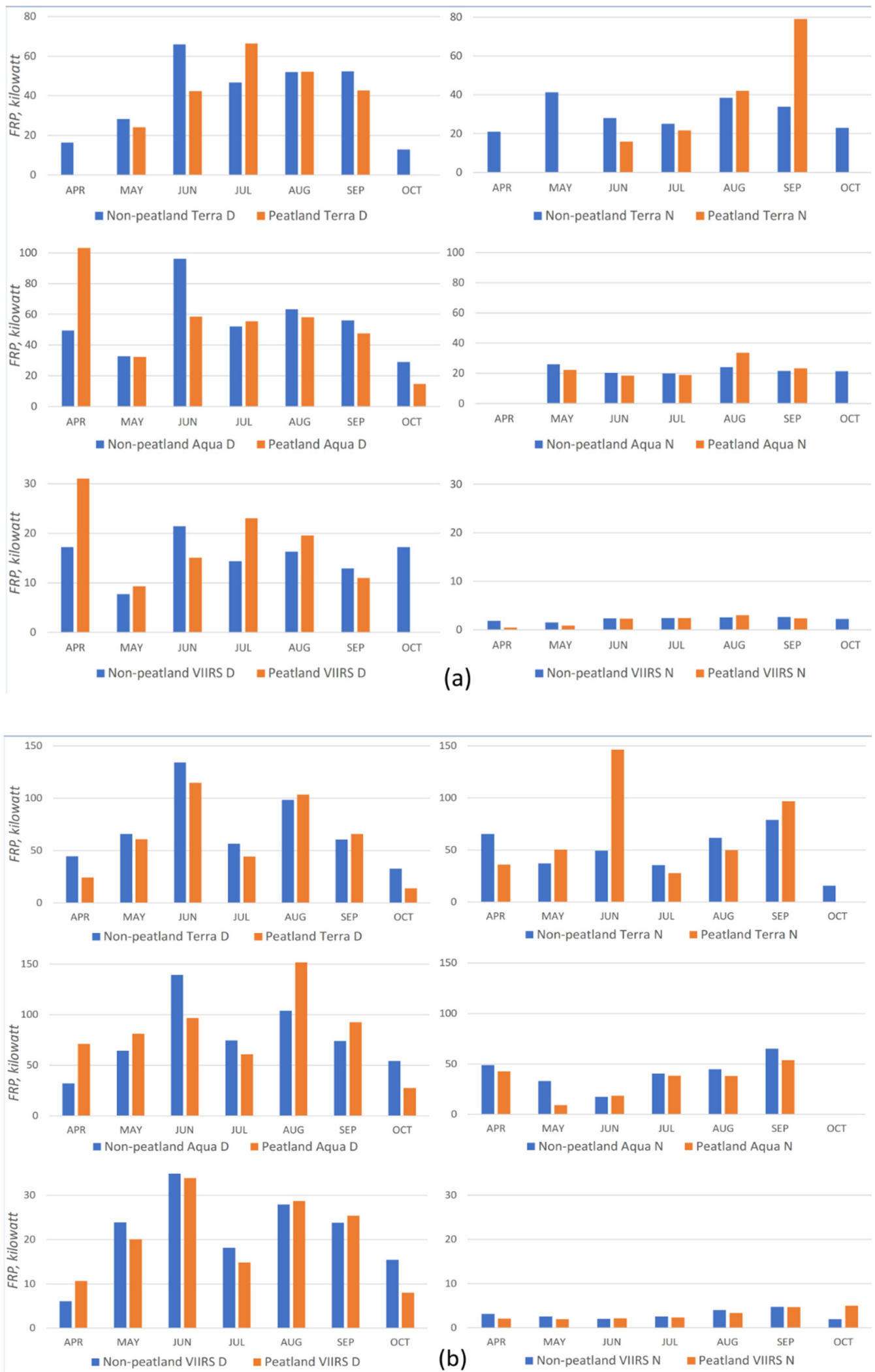

Figure 7. Seasonal dynamics of Fire Radiative Power (FRP) across bog and non-bog areas: (a)—Tokma area; (b) - Khanda area.

Considerable satellite-observed fire activity over permafrost-underlined peatlands during the last few years has been supported by accounts of local residents. However, 
hunters additionally witnessed an increasing number of smoldering fires, which are not normally detected by satellites. One hunter noted that such a fire took place in swampland in January of 2017 and even recorded the burning on his cell phone, since it was an unusual event for this area. Another hunter in winter saw flames across the river for two evenings, then went to the location to check and observed an underground burning sometimes in the form of open fire and sometimes in the form of smoke. A third hunter saw smoke coming from underground that was initially remote, but in a few months approached his subsistence trail and a nearby forest road. During fieldwork in the summer of 2021, we documented a peatland smoldering fire. Both our own and local hunters' observations of smoldering fires have not been supported by visual inspection of satellite images. Smoke was not visible on high-resolution images, heat effects were not detected on Sentinel2 images, and not captured by MODIS and VIIRS. A comparison of autumn and spring images did not allow us to draw unambiguous conclusions that something had changed. This confirms the existing challenges of detection, as well as the need for ground truthing in addition to local and Indigenous input for understanding smoldering fire dynamics [9].

Smoldering fires are not always visible, even when in proximity. One of the local hunters identified their location by the presence of excessive frost on trees. Snow around smoldering fires does not always melt completely, only around their rims. Deep snow can gradually extinguish fires. Although an area may be small, peat's thickness can be as much as $4 \mathrm{~m}$ deep. Fires in swampy areas often initiate from burning regular forest, and in some instances are caused by humans. In one case, a hunter noted that geologists lit a fire to make tea which initiated another fire under the snow, resulting in burning down of kaltus that was usually a place for reindeer foraging during the wintertime. Another resident remembers a fire he had set up in a navolok by making tea in November, and then putting it out by himself:

There was snow, probably $40 \mathrm{~cm}$, so there was a little bit of coal and I left. I should have at least raked in the snow, but the snow was everywhere ... So, in 2 days I passed again by the place where tea was brewed. I felt smoke and decided to go back to this place where I brewed tea. I came, and there, e-my, there, probably, already 5-10 m, well, in diameter everything burned out. Where there were such small thin cedar and spruce trees, they fell. And, most importantly, there was a lowland and into the ridge it all goes. And there, under the moss from below, it began to smolder, smolder, smolder, and in 2 days, it all burned out. Well, instead of hunting I was there extinguishing that fire. Well, there is no such fire, where you can see that this edge is here, let's say there is no snow, but somehow it has already melted, and then that snow lies, and there it smolders, too, that's all, moss, yes, the roots are smoldering. I chop off with an axe, and there are coals, sparks like that (male, 65, Tokma, 5 August 2021).

He noted that fires increase in frequency, intensity, and scale as a result of drier than usual summer seasons. The damage is especially higher in peatlands with permafrost, since trees have roots near the surface. These roots burn and the trees fall even if it is a low-intensity fire. Burning tree roots also allow fires to cross forest clearings underground and smolder in the wintertime.

\section{Discussion}

This paper demonstrates the importance of combining landscape studies, local and Indigenous knowledge, and remote sensing analysis for better understanding of wildfires in areas with discontinuous permafrost. The results of such a multi-source 'triangulation' approach confirm that wildfires in subarctic Siberian taiga have been increasing in number, intensity, and prevalence across different landscapes and seasons. While there is a significant volume of information gathered on wildfires and management for boreal forests, our study calls to consider specific landscapes more carefully within taiga which have distinct value for local and Indigenous communities. Better understanding of locally differentiated landscapes allows researchers and decision makers to take into account not only economic, but also social and cultural significances of burned areas. This brings into consideration fire 
impacts on subsistence infrastructure and on practices of local and Indigenous communities that have been largely disregarded by decision makers due to limited budgets for wildfire management and priorities based exclusively on economic valuation. As demonstrated by Anna Sirina [39], hunting infrastructure was better monitored and managed against wildfires during the Soviet period when sable furs collected by local hunters were priced higher on the global market. Currently, oil, gas, and wood have higher market values, thus areas of their extraction are increasingly monitored and managed against wildfires at the expense of other regions. The perception of wildfire impacts reflects these biased priorities by focusing on industrial forest cover loss rather than on impacts upon other landscapes vital for local and Indigenous livelihoods.

Moreover, interviews with forest management experts in Irkutsk demonstrated that smoldering permafrost peatland fires have not yet become a point of concern for regional authorities. Limited attention to these fire events finds some support among researchers who recommend focusing fire suppression efforts only in areas that have significant social, natural, and economic value [21]. However, this perspective does not take into account losses of hunting infrastructure and reindeer habitat, which are instrumental for local subsistence. Moreover, it does not account for the growing evidence of carbon losses due to smoldering peatland fires [58] as well as the risks of significant alterations of ecosystems from repeated disturbances, such as reburns [30,59,60].

Examination of MODIS and VIIRS imagery showed a much longer fire danger period for permafrost peatlands than estimated for this latitude by Kharyuk et al. [21]. At the same time, characteristics of permafrost peatland wildfires exhibit considerable variation. For example, the higher variability of fire intensity in non-peatland areas in Tokma (Figure 6) can be related to its larger proportion of forest stands. The higher values of FRP in April (Figure 7) can be explained by burning of logging residues that usually takes place in logging sites during that month; thermal anomalies are found in areas with recent logging and near urban sites. Seasonal FRP dynamics with higher values for forests in October can be attributed to crown fires, while snow cover was already established over peatlands.

Analysis of the interviews with local community members and forestry managers suggests that local witness accounts are more aligned with the results of detailed landscape studies than regional-level assessments exclusively based on remote sensing data. Interviews indicate that wildfire frequency and areas of fire expansion are larger than what communities experienced before. Moreover, local interviewees noticed unusual characteristics of wildfires in permafrost areas. Such permafrost peatland fires usually have not been ignited during a fire season; they either come from surrounding forest or occur in fall or winter. These observations suggest that the wildfire season may be longer than reported by satellite sources if taking into account local witnesses of smoldering fires.

Local witness accounts also provide abundant evidence of more frequent overwintering "zombie fires" in the Subarctic taiga. This emerging phenomenon is concerning for local residents, and may point to a new forest fire regime with significant consequences for both local subsistence and global carbon cycling [3]. Poor visibility of "zombie fires" on satellite imagery in addition to a general lack of knowledge about these fire events in permafrost areas complicate further progress in fire assessment and management in subarctic taiga and tundra. Working with local communities may often be the primary and sole means to develop our knowledge base on this rapidly propagating phenomenon.

\section{Conclusions}

Empowerment of local communities helps us understand, prevent, and manage peatland fires [61]. This study presents additional evidence that local accounts and Indigenous knowledge provide valuable and detailed information on fire activity in fire-affected remote regions which are not available from other sources. Furthermore, this information provides an increasingly accurate and elaborate understanding of wildfire activity and its impacts compared to regional-level assessments based exclusively on remote sensing or official reporting. This is especially relevant for smoldering fires, including "zombie fires", in 
permafrost areas in the Arctic and subarctic. In the last decade wildfires in the Subarctic Siberian taiga increased in number, intensity, and geographical spread. With permafrost degradation, boreal peatland fires have been increasing in similarity with the peatland fires of warmer areas. Drastic changes in fire regime and management are needed to introduce early measures to extinguish them since this becomes increasingly challenging at their later stages [62]. In addition, detailed accounts of wildfires and close collaboration between fire prevention agencies and local and Indigenous communities on wildfire prevention and monitoring can help with developing good wildfire management practices. Higher resolutions of thermal anomalies and land cover changes are also needed in order to match detailed observations from local and Indigenous community members, such as ignition points, seasonal dynamics, and other characteristics of wildfires.

Supplementary Materials: The following supporting information can be downloaded at: https:// www.mdpi.com/article/10.3390/land11030322/s1, Table S1: Confusion matrix for the land cover maps.

Author Contributions: Conceptualization, V.K. and A.N.P.; methodology, V.K., A.N.P., E.R. and O.S.; investigation, V.K., I.B. and N.K.; data curation, V.B., E.R. and O.S.; writing-original draft preparation, V.K.; writing - review and editing, V.K. and A.N.P.; visualization, O.S. and V.B.; project administration, V.K.; funding acquisition, V.K. and A.N.P. All authors have read and agreed to the published version of the manuscript.

Funding: This research was funded by the National Science Foundation, grant number 1748092, and by the Tyumen Oblast Government, as part of the West-Siberian Interregional Science and Education Center's project award number 89-DON (1). Landscape data analysis was funded by the Russian Academy of Sciences (AAAA-A21-121012190059-5, AAAA-A21-121012190063-2, AAAA-A21121012190056-4).

Institutional Review Board Statement: The study was conducted in accordance with the Declaration of Helsinki, and was determined to be research that is exempt from IRB review under DHHS regulatory category 2 by the Institutional Review Board of the George Washington University (protocol code NCR191103, 1 March 2019).

Informed Consent Statement: Informed consent was obtained from all subjects involved in the study.

Data Availability Statement: Data on land cover and wildfire derived from the remote sensing analysis is available upon request from the authors.

Acknowledgments: This research was conducted on territories of traditional land use of Evenki Indigenous People. The research team is grateful to the informants who shared their time, stories, and expertise.

Conflicts of Interest: The authors declare no conflict of interest.

\section{References}

1. McCarty, J.L.; Aalto, J.; Paunu, V.V.; Arnold, S.R.; Eckhardt, S.; Klimont, Z.; Wilson, S. Reviews and syntheses: Arctic fire regimes and emissions in the 21st century. Biogeosciences 2021, 18, 5053-5083. [CrossRef]

2. Irannezhad, M.; Liu, J.; Ahmadi, B.; Chen, D. The dangers of Arctic zombie wildfires. Science 2020, 369, 1171. [CrossRef] [PubMed]

3. Scholten, R.C.; Jandt, R.; Miller, E.A.; Rogers, B.M.; Veraverbeke, S. Overwintering fires in boreal forests. Nature 2021, 593, 399-404. [CrossRef]

4. Masrur, A.; Petrov, A.N.; DeGroote, J. Circumpolar spatio-temporal patterns and contributing climatic factors of wildfire activity in the Arctic tundra from 2001-2015. Environ. Res. Lett. 2018, 13, 014019. [CrossRef]

5. Li, X.Y.; Jin, H.J.; Wang, H.W.; Marchenko, S.S.; Shan, W.; Luo, D.L.; Jia, N. Influences of forest fires on the permafrost environment: A review. Adv. Clim. Chang. Res. 2021, 12, 48-65. [CrossRef]

6. French, H.M. The Periglacial Environment; John Wiley \& Sons: Hoboken, NJ, USA, 2018; p. 515.

7. Minsley, B.J.; Pastick, N.J.; Wylie, B.K.; Brown, D.R.N.; Kass, M.A. Evidence for nonuniform permafrost degradation after fire in boreal landscapes. J. Geophys. Res. Earth Surf. 2016, 121, 320-335. [CrossRef]

8. Kirdyanov, A.V.; Saurer, M.; Siegwolf, R.; Knorre, A.A.; Prokushkin, A.S.; Churakova, O.V.; Büntgen, U. Long-term ecological consequences of forest fires in the continuous permafrost zone of Siberia. Environ. Res. Lett. 2020, 15, 034061. [CrossRef]

9. Witze, A. The Arctic is burning like never before-And that's bad news for climate change. Nature 2020, 585, 336-337. [CrossRef]

10. Huang, X.; Rein, G. Downward spread of smouldering peat fire: The role of moisture, density and oxygen supply. Int. J. Wildland Fire 2017, 26, 907-918. [CrossRef] 
11. Poulter, B.; Christensen, N.L., Jr.; Halpin, P.N. Carbon emissions from a temperate peat fire and its relevance to interannual variability of trace atmospheric greenhouse gases. J. Geophys. Res. Atmos. 2006, 111, D06301. [CrossRef]

12. Sirin, A.A.; Makarov, D.A.; Gummert, I.; Maslov, A.A.; Gul'be Ya, I. Glubina progoraniya torfa i poteri ugleroda pri lesnom podzemnom pozhare (Depth of Peat Burning and Carbon Losses from an Underground Forest Fire). Lesovedeniye 2019, 5, 410-422.

13. Mack, M.; Bret-Harte, M.; Hollingsworth, T.; Jandt, R.; Schuur, E.; Shaver, G.; Verbyla, D. Carbon loss from an unprecedented Arctic tundra wildfire. Nature 2011, 475, 489-492. [CrossRef]

14. Hu, Y.; Fernandez-Anez, N.; Smith, T.E.L.; Rein, G. Review of emissions from smouldering peat fires and their contribution to regional haze episodes. Int. J. Wildland Fire 2018, 27, 293-312. [CrossRef]

15. Minayeva, T.; Sirin, A.A.; Stracher, G.B. The peat fires of Russia. In Coal and Peat Fires: A Global Perspective; Stracher, G.B., Prakash, A., Sokol, E.V., Eds.; Elsevier: Amsterdam, The Netherlands, 2013; pp. 376-394.

16. Sirin, A.; Minayeva, T.; Vozbrannaya, A.; Bartalev, S. Kak izbezhat' torfyanykh pozharov? (How to avoid peat fires?). Nauka Ross. 2011, 2, 13-21.

17. Parish, F.; Sirin, A.; Charman, D.; Joosten, H.; Minayeva, T.; Silvius, M.; Stringer, L. Assessment on Peatlands, Biodiversity and Climate Change; Main Report; Global Environment Centre, and Wageningen: Kuala Lumpur, Malaysia, 2008.

18. Minayeva, T.Y.; Sirin, A.A. Biologicheskoye raznoobraziye bolot i izmeneniye klimata (Biological diversity of swamps and climate change). Uspekhi Sovrem. Biol. (Successes Curr. Biol.) 2011, 131, 393-406.

19. Rounsevell, M.; Fischer, M.; Torre-Marin Rando, A.; Mader, A. (Eds.) The IPBES Regional Assessment Report on Biodiversity and Ecosystem Services for Europe and Central Asia; Secretariat of the Intergovernmental Science-Policy Platform on Biodiversity and Ecosystem Services: Bonn, Germany, 2018.

20. Kharuk, V.I.; Ponomarev, E.I.; Ivanova, G.A.; Dvinskaya, M.L.; Coogan, S.C.; Flannigan, M.D. Wildfires in the Siberian taiga Ambio 2021, 50, 1-22. [CrossRef] [PubMed]

21. Kopoteva, T.A.; Kuptsova, V.A. Pyrogenic Factor on Marie Bogs of the Amur Region. Bull. North-Eastern Sci. Center Far Eastern Branch Russ. Acad. Sci. 2011, 3, 37-41.

22. Swindles, G.T.; Morris, P.J.; Mullan, D.; Watson, E.J.; Turner, T.E.; Roland, T.P.; Amesbury, M.J.; Kokfelt, U.; Schoning, K.; Pratte, S.; et al. The long-term fate of permafrost peatlands under rapid climate warming. Sci. Rep. 2015, 5, 17951. [CrossRef]

23. Akhmet'yeva, N.P.; Belova, S.E.; Dzhamalov, R.G.; Kulichevskaya, I.S.; Lapina, Y.Y.; Mikhaylova, A.V. Yestestvennoye vosstanovleniye bolot posle pozharov (Natural restoration of bogs after fires). Vodn. Resur. (Water Resour.) 2014, 41, 343-354.

24. Ciavarella, A.; Cotterill, D.; Stott, P.; Kew, S.; Philip, S.; van Oldenborgh, G.J.; Skålevåg, A.; Lorenz, P.; Robin, Y.; Otto, F.; et al. Prolonged Siberian heat of 2020 almost impossible without human influence. Clim. Chang. 2021, 166, 9. [CrossRef]

25. Flannigan, M.; Stocks, B.; Turetsky, M.; Wotton, M. Impacts of climate change on fire activity and fire management in the circumboreal forest. Glob. Chang. Biol. 2009, 15, 549-560. [CrossRef]

26. Turetsky, M.R.; Kane, E.S.; Harden, J.W.; Ottmar, R.D.; Manies, K.L.; Hoy, E.; Kasischke, E.S. Recent acceleration of biomass burning and carbon losses in Alaskan forests and peatlands. Nat. Geosci. 2011, 4, 27-31. [CrossRef]

27. Joosten, H.; Sirin, A.; Couwenberg, J.; Laine, J.; Smith, P. The role of peatlands in climate regulation. In Peatland Restoration and Ecosystem Services: Science, Policy and Practice; Cambridge University Press: Cambridge, UK, 2016; pp. 63-76. [CrossRef]

28. Kirillina, K.; Shvetsov, E.G.; Protopopova, V.V.; Thiesmeyer, L.; Yan, W. Consideration of anthropogenic factors in boreal forest fire regime changes during rapid socio-economic development: Case study of forestry districts with increasing burnt area in the Sakha Republic, Russia. Environ. Res. Lett. 2020, 15, 035009. [CrossRef]

29. Bondur, V.G.; Mokhov, I.I.; Voronova, O.S.; Sitnov, S.A. Satellite Monitoring of Siberian Wildfires and Their Effects: Features of 2019 Anomalies and Trends of 20-Year Changes. Dokl. Earth Sci. 2020, 492, 370-375. [CrossRef]

30. Shvetsov, E.G.; Kukavskaya, E.A.; Shestakova, T.A.; Laflamme, J.; Rogers, B.M. Increasing fire and logging disturbances in Siberian boreal forests: A case study of the Angara region. Environ. Res. Lett. 2021, 16, 115007. [CrossRef]

31. Kuklina, V.; Petrov, A.N.; Krasnoshtanova, N.; Bogdanov, V. Mobilizing Benefit-Sharing Through Transportation Infrastructure: Informal Roads, Extractive Industries and Benefit-Sharing in the Irkutsk Oil and Gas Region, Russia. Resources $2020,9,21$. [CrossRef]

32. Strack, M.; Softa, D.; Bird, M.; Xu, B. Impact of winter roads on boreal peatland carbon exchange. Glob. Chang. Biol. 2018, 24, e201-e212. [CrossRef]

33. Reuters. Russia's Yakutia Province Governor Warns of More Deadly Wildfires Next Year. Available online: https://www. reuters.com/world/russias-yakutia-province-governor-warns-more-deadly-wildfires-next-year-2021-09-09/ (accessed on 11 November 2021)

34. Fletcher, M.-S.; Romano, A.; Connor, S.; Mariani, M.; Maezumi, S.Y. Catastrophic Bushfires, Indigenous Fire Knowledge and Reframing Science in Southeast Australia. Fire 2021, 4, 61. [CrossRef]

35. Vorobiev, V. Atlas. Irkutsk Region: Ecological Conditions of Development; Roskartografiia, Institut geografii SO RAN: Irkutsk, Moscow, 2004

36. Suvorov, E.G.; Makarov, S.A. Ekologicheski Orientirovannoe Planirovanie Zemlepol'zo Vaniya v Baikal'skom Regione. Kovyktinskoe Gazokonden Satnoe Mestorozhdenie; Suvorov, E.G., Makarov, S.A., Eds.; Inst. Geogr. Sib. Otd. Ross. Akad. Nauk.: Irkutsk, Russia, 2004; p. 159.

37. Nekrasov, I.A. Geocriological Map 1979 Baikal-Amur Mainline, 1:2500,000; Nekrasov, I.A., Ed.; GUGK: Moscow, Russia, 1979. 
38. Sirina, A. Evenki i Eveny v Sovremennom mire: Samosoznaniye, Prirodopol'zo-Vaniye, Mirovozzreniye; Vostochnaya Literature: Moscow, Russia, 2012; p. 604. (In Russian)

39. Sirina, A.A. Evenki fire and forest ontology in the context of the wildfires in Siberia. Polar Sci. 2021, 29, 100726. [CrossRef]

40. Gazprom. Kovyktinskoye. 2019. Available online: https://www.gazprom.ru/projects/kovyktinskoye/ (accessed on 7 October 2019). (In Russian)

41. Forestry Agency of the Irkutsk Region. Order about the Structure of the Forestry Agencies of the Irkutsk Region. 2008. Available online: https:/ / docs.cntd.ru/document/561506213 (accessed on 15 October 2021).

42. Federal Forestry Agency, Control Zones. Available online: http://rosleshoz.gov.ru/activity/forest_security_and_protection/ fires/zones (accessed on 15 May 2021).

43. Markova, A. Ministr Lesnogo Kompleksa Irkutskoy oblasti: O Nelegal'nykh Vyrubkakh, Pozharakh i Lesovosstanovlenii. Available online: https:/ /www.irk.ru/news/articles/20210927/wood/ (accessed on 7 October 2021).

44. Government of the Russian Federation. Decree 'Fire Safety Rules in Forests'; Government of the Russian Federation: Moscow, Russia, 2020.

45. Rosleskhoz. Form of a Model Forest Land Lease Agreement. 26 July 2011; No. 319. Available online: http:/ / government.ru/en/ search $/$ ?q=Form \%20of\%20a\%20Model\%20Forest $\% 20 L a n d \% 20 L$ ease $\% 20$ Agreement\&dt.till=22.02.2022\&dt.since=7.05.2012\& sort=rel\&type $=$ (accessed on 1 February 2022).

46. Prishchepov, A.V.; Myachina, K.V.; Kamp, J.; Smelansky, I.; Dubrovskaya, S.; Ryakhov, R.; Grudinin, D.; Yakovlev, I.; Urazaliyev, R. Multiple trajectories of grassland fragmentation, degradation, and recovery in Russia's steppes. Land Degrad. Dev. 2021, 32, 3220-3235. [CrossRef]

47. Belgiu, M.; Drăguț, L. Random forest in remote sensing: A review of applications and future directions. ISPRS J. Photogramm. Remote Sens. 2016, 114, 24-31. [CrossRef]

48. Schroeder, W.; Oliva, P.; Giglio, L.; Csiszar, I.A. The New VIIRS 375m active fire detection data product: Algorithm description and initial assessment. Remote Sens. Environ. 2014, 143, 85-96. [CrossRef]

49. Giglio, L.; Schroeder, W.; Justice, C.O. The collection 6 MODIS active fire detection algorithm and fire products. Remote Sens. Environ. 2016, 178, 31-41. [CrossRef] [PubMed]

50. Justice, C.O.; Giglio, L.; Korontzi, S.; Owens, J.; Morisette, J.T.; Roy, D.; Descloitres, J.; Alleaume, S.; Petitcolin, F.; Kaufman, Y. The MODIS fire products. Remote Sens. Environ. 2002, 83, 244-262. [CrossRef]

51. EarthData. Fire Information for Resource Management System (FIRMS). Available online: https://earthdata.nasa.gov / earthobservation-data/near-real-time/firms (accessed on 15 February 2021).

52. Fire Information for Resource Management System (FIRMS). Archive Download. Available online: https:/ / firms.modaps.eosdis. nasa.gov/download/ (accessed on 15 October 2021).

53. Wooster, M.J.; Zhukov, B.; Oertel, D. Fire radiative energy for quantitative study of biomass burning: Derivation from the BIRD experimental satellite and comparison to MODIS fire products. Remote Sens. Environ. 2003, 86, 83-107. [CrossRef]

54. Kuklina, V.; Bilichenko, I.; Bogdanov, V.; Kobylkin, D.; Petrov, A.; Shiklomanov, N. Informal road networks and sustainability of Siberian boreal forest landscapes: Case study of the Vershina Khandy taiga. Environ. Res. Lett. 2021, 16, 115001. [CrossRef]

55. Mamontova, N.; Klyachko, E.; Thornton, T. 'The track is never the same': The fluidity of geographic terminology and conceptualisation of space among Ewenki. Hunt. Gatherer Res. 2020, 4, 311-337. [CrossRef]

56. Xiong, X.; Angal, A.; Chang, T.; Chiang, K.; Lei, N.; Li, Y.; Sun, J.; Twedt, K.; Wu, A. MODIS and VIIRS Calibration and Characterization in Support of Producing Long-Term High-Quality Data Products. Remote Sens. 2020, 12, 3167. [CrossRef]

57. Xiong, X.; Butler, J. MODIS and VIIRS Calibration History and Future Outlook. Remote Sens. 2020, 12, 2523. [CrossRef]

58. McCarty, J.L.; Smith, T.E.L.; Turetsky, M.R. Arctic fires re-emerging. Nat. Geosci. 2020, 13, 658-660. [CrossRef]

59. Buma, B.; Weiss, S.; Hayes, K.; Lucash, M. Wildland fire reburning trends across the US West suggest only short-term negative feedback and differing climatic effects. Environ. Res. Lett. 2020, 15, 034026. [CrossRef]

60. Johnstone, J.F.; Hollingsworth, T.N.; Chapin, F.S., III; Mack, M.C. Changes in fire regime break the legacy lock on successional trajectories in Alaskan boreal forest. Glob. Change Biol. 2010, 16, 1281-1295. [CrossRef]

61. Nasrul, B. Program of Community Empowerment Prevents Forest Fires in Indonesian Peat Land. Procedia Environ. Sci. 2013, 17, 129-134. [CrossRef]

62. Greenpeace. Rekomendatsii po Tusheniyu Torfyanykh Pozharov na Osushennykh Bolotakh (Recommendations for Extinguishing Peat Fires in Drained Swamps). 2020. Available online: https://gfmc.online/wp-content/uploads/Greenpeace-Russia-Peat-FireManagement-Recommendations-2nd-Edition-2020.pdf (accessed on 12 November 2021). 